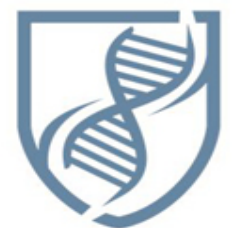

Journal of Bioscience and Applied Research

\section{JBAAR}

WWW.JBAAR.ORG

\title{
Distribution of bacteria in Lake Qarun, AL Fayoum, Egypt (2014 -2015) in relation to its physical and hydrochemical characterization
}

\author{
Mohamed Tawfiek Shaaban ${ }^{1}$, Hassan A.H. Ibrahim², Amer Ahmed Mohammed Hanafi ${ }^{3}$ \\ Botany Department, Faculty of Science, Menoufia University ${ }^{1,3}$; National Institute of Oceanography and \\ Fisheries (NIOF), Alexandria ${ }^{2}$, Egypt \\ (Corresponding author email : dr_mohamedtawfiek@yahoo.com)
}

\begin{abstract}
The bacteriological monitoring of Lake Qarun water and sediment (aerobic heterotrophs, Staphylococcus sp., Vibrio sp. Aeromonas sp., S. feacalis, E. coli, and total coliform sp.) through the period of study (2014-2015) was carried out. Six common bacterial isolates were fully identified as; Bacillus firmus, Bacillus stratosphericus, Exiguobacterium mexicanum, Stenotrophomonas rhizophila, Halomonas stevensii, and Halomonas korlensis based on partial sequencing of $16 \mathrm{Sr}$ DNA. In addition, physical and chemical analyses of Lake Qarun water and sediment $(\mathrm{pH}$, temperature, salinity, dissolved oxygen, BOD, COD, and nutrients) were estimated. The $\mathrm{pH}$ varied between 7.08 at sit $\mathrm{I}$ and 8.73 at sit $\mathrm{V}$. The temperature varied between $15.6^{\circ} \mathrm{C}$ at sit VIII and $32.2^{\circ} \mathrm{C}$ at sit I. The salinity ranged between $3.18 \%$ at sit I and $51.72 \%$ at sit III. The dissolved oxygen fluctuated between $3.89 \mathrm{md} / \mathrm{l}$ at sit VI and 8.96 $\mathrm{md} / \mathrm{l}$ at sit IV. The BOD ranged between $1.08 \mathrm{mg} / \mathrm{l}$ at sit VIII and $6.47 \mathrm{mg} / \mathrm{l}$ at sit IV. The COD varied between $11.36 \mathrm{mg} / \mathrm{l}$ at sit I and $53.64 \mathrm{mg} / \mathrm{l}$ at sit VIII. The phosphate in lake water varied between $1.453 .4 \mu \mathrm{g} / \mathrm{l}$ at sit VIII and $498.4 \mu \mathrm{g} / \mathrm{l}$ at sit I. The ammonia ranged between $14.73 \mu \mathrm{g} / \mathrm{l}$ at sit II and $1485 \mu \mathrm{g} / \mathrm{l}$ at sit I. The nitrite varied between $4.10 \mu \mathrm{g} / \mathrm{l}$ at sit IV and $646.5 \mu \mathrm{g} / \mathrm{l}$ at sit I. The nitrate varied between $14.79 \mu \mathrm{g} / \mathrm{l}$ at sit III and $2138 \mu \mathrm{g} / \mathrm{l}$ at sit I. The silicate fluctuated between $894.6 \mu \mathrm{g} / \mathrm{l}$ at sit VI and 4682 $\mu \mathrm{g} / \mathrm{l}$ at sit VII.
\end{abstract}

Keywords: Distribution of bacteria, physical characterization, hydrochemical characterization, Lake Qarun.

\section{Introduction}

Lake Qarun is the only enclosed, saline, highly eutrophied lake among the inland lakes of Egypt, snuggling forty-five meters below sea level into the lowest, northern section of El- Fayoum Depression, Egypt. Although Lake Qarun designated as protected area back in 1989, the Lake has hardly been protected from various polluting elements. It suffers from a serious water pollution problem which is due to uncontrolled solid and liquid domestic and industrial waste disposal practices, in addition to agrochemical contamination and lack of sustainable wastewater management. Many fish farms were established around this Lake (Mansour and Sidky, 2003). The Lake suffered drastic chemical changes during the last years where it is used as a general reservoir for agricultural wastewaters drainage of El-Fayoum Governorate, as well as for the drainage of the fish farms. Therefore, its salinity increases progressively which affects greatly the Lake biota. In addition, the exacerbation of eutrophication of the Lake's water is caused by the nutrient load from the agricultural drainage water (Sabae and Ali, 2004). Moreover, groundwater appears to be continuously seeping from a number of sub-surface springs at the Lake bottom. The Egyptian Company for Salts and Mineral (EMISAL) located on the southern coast of the Lake, where a part, known as Batnat Abo Ksah, was cutoff from the Lake and divided into number of concentrating ponds, to concentrate the Lake water as much as 10 times the original salinity. The effluents of EMISAL brine water discharged also into the Lake and caused increasing in the most parameters (Shaltout et al., 2015). Lake monitoring may provide early warning signs of ecosystem degradation resulting foe example from contaminant inputs, nutrient addition, sediment runoff. By monitoring the physical, chemical, and biological status of a Lake, changes for many aspects of the ecosystem can be 
detected quickly, and hopefully, harmful impacts can be eliminated before their consequences become unmanageable (Leiser et al., 2015). Therefore, the present study was aimed for the assessment of bacterial distribution in Lake Qarun (2014-2015) in relation to study the seasonal changes at the physical and chemical properties of water and sediments.

\section{Materials and Methods}

\section{Study area}

In the current study, water and sediment samples were collected from the Qarun Lake during summer 2014 and spring 2015. Lake Qarun (Figure 1), located about 27 kilometers north of Al Fayoum City and 80 kilometers southwest of Cairo. Al Fayoum is not far from the Nile Valley, and it is one of Egypt's most treasured natural landmarks and a resource that has helped support human culture for some 8,000 years. It is the only natural contemporary lake of any size in Middle Egypt. It is therefore rich in both natural and archaeological resources. All samples were collected from eight stations that are distributed along Lake as shown on the map (Figure 1). However, they are included as follows:

$\checkmark$ Station I: From the front of the Bank of Bats,

$\checkmark$ Station II: From the front of machines, agricultural drainage (in front of Treasures village),

$\checkmark$ Station III: From the front of EL-Auberge,

$\checkmark$ Station IV: From far northeast Qarun Lake,

$\checkmark$ Station V:From the front of the Lesan Abunimah,

$\checkmark$ Station VI: From the front of the village Shakshuk,

$\checkmark$ Station VII: From the front of Valley Bank,

$\checkmark$ Station VIII: From the front of the village of Egypt for reconstruction station.

\section{Methods}

\section{Sample collection for bacterial isolation}

Water samples were collected in $500 \mathrm{ml}$ sterile screwcaped bottles as previously described by Austin (1988). The central portion of the top $2 \mathrm{~cm}$ sediment samples was taken out with the help of a sterile spatula. The samples were then transferred to a sterile polythene bag.

\section{Isolation of bacteria from water and sediment samples}

Serial dilutions from $10^{-2}$ to $10^{-6}$ were made using filtered sterilized distilled water. A portion $(0.1 \mathrm{ml})$ from each appropriately diluted sample was used to inoculate plates prepared with nutrient agar for counting aerobic heterotrophs. The sediment samples were collected by sediment sampler (Peterson grab), it was sterilized with alcohol before sampling at each station.

Plates were incubated at $30-37^{\circ} \mathrm{C}$ for $24-48 \mathrm{~h}$. Plates of seven selective media used were inoculated with $1 \mathrm{ml}$ of appropriately dilution sample for counting the different bacterial groups: Staphylococci, Vibrios, Aeromonas, Salmonella, Shigella, while total coliforms, faecal Streptococci and Escherichia coli were estimated according to ISO (SO 9308/1; 1990 and ISO 7899/2; 1984).
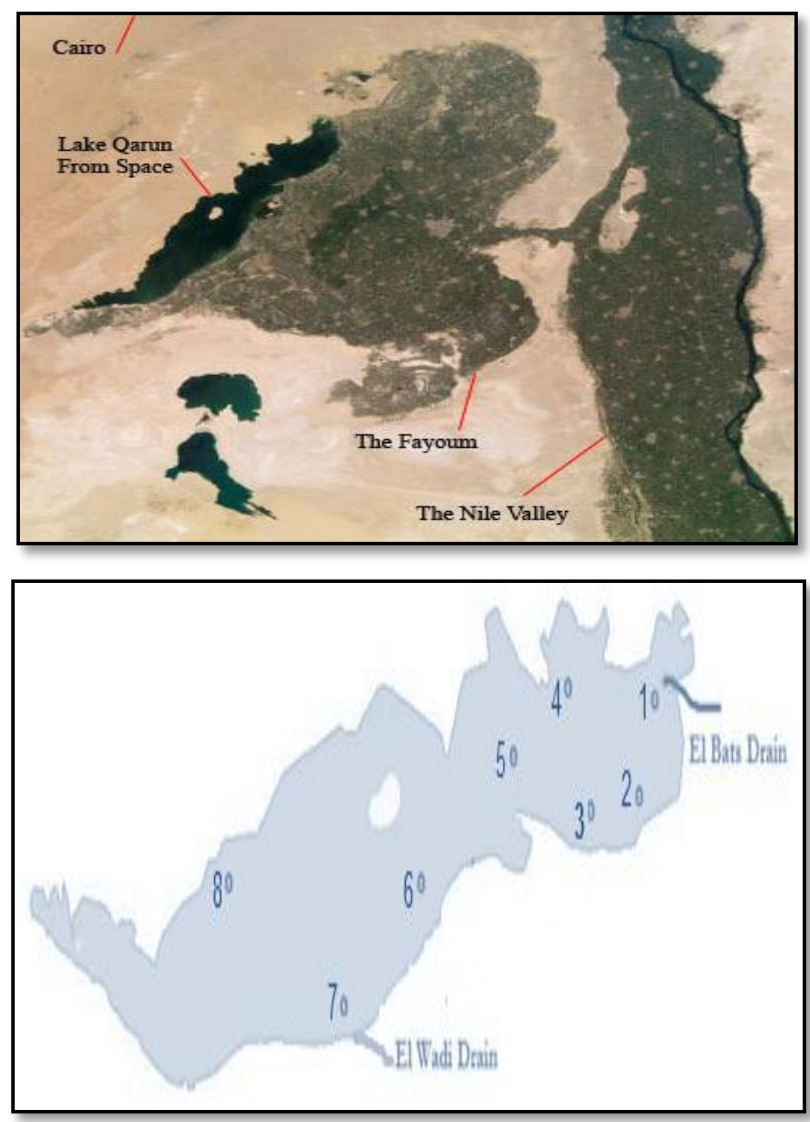

Figure 1: The location of Lake Qarun in the southwest of Cairo and from the Nile Valley (http://www.touregypt.net) and distribution of sampling sites on the Lake

\section{Characterization of the selected bacteria Genotype characterization}

The common bacterial isolates were cultured in NB medium for 2 days and genomic DNAs were extracted with genomic DNA extraction protocol of GeneJet genomic DNA purification Kit (Fermentas). PCR using Maxima Hot Start PCR Master Mix (Fermentas) and PCR clean up to the PCR product using GeneJET ${ }^{\mathrm{TM}}$ PCR Purification Kit (fermentas) were determined at Sigma Scientific Services Co. Egypt. The sequencing to the PCR product on GATC Company was made by using ABI 3730xl DNA Sequencer by using universal primaries (16S 27F; 5` AGAGTTTGATCCTGGCTCAG 3` and 16S 1492R; $3{ }^{`}$ GGTTACCTTGTTACGACTT 5`). Bacterial isolates were submitted to genotypic characterization through 16S rRNA gene technique. The sequences were compared with known sequences in the Gene Bank nucleotide database and identified as the nearest phylogenetic neighbor with the highest similarity percent (Hentschel et al., 2001). 


\section{Phenotype characterization}

Phenotypic characteristics such as Gram's staining, motility, cultural characteristics, catalase, oxidase and IMViC test of all the marine bacterial isolate was studied by adopting standard procedures. Effect of sodium chloride, pH level, and temperature on growth was tested. All the tests were performed by adopting standard procedures (Garrity et al., 2005).

\section{Physical analyses of lake water}

The following operations ( $\mathrm{pH}$, temperature and salinity) were performed for each water sample, some of which were performed in the field. Salinity was measured using Beckman (No. R.S.7C) salinometer calibrated using standard sea water. The conductivity ratio was measured to the nearest $7 \times 10^{-5}$ (Wooster et al., 1969).

\section{Hydrochemical analyses of lake water and sediment} Dissolved oxygen (DO)

Dissolved oxygen was determined by Winkler's method (Strickland and Parsons, 1972). Titration was carried out using $200 \mathrm{ml}$ of the sample against $0.025 \mathrm{~N}$ solution of sodium thiosulfate. However, the thiosulfate solution was standardized against potassium bi-iodate solution $0.025 \mathrm{~N}$. The dissolved $\mathrm{O}_{2}$ expressed in $\mathrm{mgO}_{2} \mathrm{I}^{-1}$ was calculated by the following equation: $\left[\mathrm{DO} \mathrm{mg} \mathrm{l}^{-1}\right)=$ ( $\mathrm{V}_{\text {titrant }} \times \mathrm{N}_{\text {titrant }} \times$ 8000)/ $\mathrm{V}_{\text {sample }}$.

Biological (BOD) and chemical oxygen demand (COD)

Water samples for BOD determination were collected in parallel with DO samples in $300 \mathrm{ml}$ BOD bottles and avoided formation of air bubbles. The bottles were then incubated in the dark for five days at $27^{\circ} \mathrm{C}$. After that, dissolved oxygen was determined by Winkler's method and expressed in $\mathrm{mg} \mathrm{O}_{2} \mathrm{l}^{-1}$. The BOD was calculated throw the following equation: [BOD $\left(\mathrm{mgO}_{2} \mathrm{l}^{-1}\right)=\mathrm{D} 1$ - D2] (APHA, 1992); Where: $\mathrm{D} 1=$ initial dissolved oxygen concentration $\left(\mathrm{mgO}_{2} \mathrm{l}^{-1}\right)$ and $\mathrm{D} 2=$ sample $\mathrm{DO}\left(\mathrm{mgO}_{2} \mathrm{l}^{-1}\right)$ after 5 days. On the other side, the chemical oxygen demand is the quantity of oxygen required to oxidize the organic matter in water, under specific conditions of oxidizing agents, temperature and time. The organic and oxidizable inorganic substance in the water sample were oxidized by potassium dichromate and then titrated against standard solution of ferrous ammonium sulphate using orthophenanthroline ferrous complex (ferroin) as an indicator (Medalla, 1951).

\section{Nutrients in lake water}

Samples for nutrient analysis were collected in polyethylene bottles of 1 liter capacity (except for inorganic phosphate) where it should be stored in hard glass bottle. Few drops of chloroform were then added to prevent biological activities. The water samples were directly deep frozen at $-25^{\circ} \mathrm{C}$ before carrying out chemical analysis (Grasshoff, 1976). The samples were filtered as soon as possible through $0.45 \mu \mathrm{m}$ membrane filter. Immediate analysis was recommended but if it wasn't possible, samples was directly deep frozen till carrying out chemical analysis. Several methods employed for the determination of dissolved phosphate Grasshoff (1976), dissolved nitrate (Strickland and Parsons, 1965), dissolved nitrite
(Grasshoff, 1976), dissolved ammonia Koroleff (1969), and dissolved silicate (Grasshoff et al., 1999) were suggested.

\section{Results}

The current study is one of the many investigations that focus on state of the lake from the bacteriological and chemical point of view. All these attempts aim to draw the attention of the government to make more of an effort to stop or control the different pollution features of the lake. The present study presented through the results the bacteriological monitoring of Lake Qarun water and sediment (aerobic heterotrophs, Staphylococcus sp., Vibrio sp. Aeromonas sp., S. feacalis, E. coli, and total coliform sp.), beside the physical and chemical parameters of Lake Qarun water and sediment ( $\mathrm{pH}$, temperature, salinity, dissolved oxygen, BOD, COD, and nutrients) that affect the distribution of different bacterial groups.

\section{Distribution of bacterial groups in the water of lake}

Aerobic heterotrophs as well as different bacterial groups recovered from water samples obtained from eight stations in lake during the period of study (2014 -2015) were isolated and counted on selective media previously described. Data are shown in Table 1. The total viable count of heterotrophic bacteria (TBVC) in lake water varied between $0.31 \times 10^{4} \mathrm{CFUml}^{-1}$ at sit VIII in winter and $200.4 \times 10^{4} \mathrm{CFUml}^{-1}$ at sit I in summer. The relative high values of TBVC were observed in spring season $\left(120.1 \times 10^{4}\right.$ $\mathrm{CFUml}^{-1}$ ) in station I and $106.4 \times 10^{4} \mathrm{CFUml}^{-1}$ in the station I in autumn, while the relative low values of TBVC were observed in many stations especially during winter season. The total viable count of Staphylococcus sp. (SC) in lake water fluctuated between $0.05 \times 10^{4} \mathrm{CFUml}^{-1}$ at station $\mathrm{V}$ in winter and 9.55x $0^{4} \mathrm{CFUml}^{-1}$ at station I in summer. The relative high values of SC were observed in spring season $\left(6.1 \times 10^{4}\right)$ in station I and $5.48 \times 10^{4} \mathrm{CFUml}^{-1}$ in the station I in autumn, while the relative low values of SC were observed in many stations especially during winter season. The total viable count of Vibrio sp. (VC) in lake water ranged between $0.03 \times 10^{3} \mathrm{CFUml}^{-1}$ at station VII in winter and $75.3 \times 10^{3} \mathrm{CFUml}^{-1}$ at station VII in summer. The relative high values of $\mathrm{VC}$ were observed in summer season $\left(30.1 \times 10^{3} \mathrm{CFUml}^{-1}\right)$ in station I in summer, while the relative low values of VC were observed in many stations especially during winter season. The total viable count of Aeromonas sp. (AC) in lake water varied between $5.54 \times 10^{2} \mathrm{CFUml}^{-1}$ at station II in winter and $60.32 \times 10^{2}$ $\mathrm{CFUml}^{-1}$ at station VII in summer. The relative high values of AC were observed in spring season $\left(30.24 \times 10^{2} \mathrm{CFUml}^{-}\right.$ ${ }^{1}$ ) in station VIII, while the relative low values of AC were observed in many stations especially during winter season. The total viable count of $S$. feacalis (SFC) in lake water fluctuated between $0.30 \times 10^{5} \mathrm{CFUml}^{-1}$ at station III in winter and $56.13 \times 10^{5} \mathrm{CFUml}^{-1}$ at station I in summer. The relative high values of SFC were observed in summer season $\left(50.8 \times 10^{5} \mathrm{CFUml}^{-1}\right)$ in station VII, while the relative low values of SFC were observed in many stations especially during winter season. The total viable count of E. coli (EC) in lake water ranged between $0.10 \times 10^{5}$ 
$\mathrm{CFUml}^{-1}$ at station VI in winter and $90.22 \times 10^{5} \mathrm{CFUml}^{-1}$ at station I in summer. The relative high values of EC were observed in summer season $\left(32.93 \times 10^{5} \mathrm{CFUml}^{-1}\right)$ in station III, while the relative low values of EC were observed in many stations especially during winter season. The total viable count of total coliform sp. (TC) in lake water fluctuated between $1.32 \times 10^{5} \mathrm{CFUml}^{-1}$ at station IV in autumn and $126.0 \times 10^{5} \mathrm{CFUml}^{-1}$ at station VII in summer. The relative high values of TC were observed in summer season $\left(100.1 \times 10^{5} \mathrm{CFUml}^{-1}\right)$ and in spring $\left(89.17 \times 10^{5}\right.$ $\mathrm{CFUml}^{-1}$ ) in station I, while the relative low values of TC were observed in many stations especially during winter season.

Distribution of bacterial groups in the sediment of lake

Aerobic heterotrophs as well as different bacterial groups recovered from sediment samples obtained from eight stations in lake during the period of study (20142015) were isolated and counted on selective media. Data are shown in Table 2. The total viable count of TBVC in lake sediment ranged between $0.15 \times 10^{5} \mathrm{CFUg}^{-1}$ at sit VII in winter and $60.49 \times 10^{5} \mathrm{CFUg}^{-1}$ at sit $\mathrm{I}$ in summer. The relative high values of TBVC were observed in summer season $\left(40.04 \times 10^{4} \mathrm{CFUg}^{-1}\right)$ in station VI, while the relative low values of TBVC were observed in many stations especially during winter season. The total viable count of SC in lake sediment varied between $1.74 \times 10^{4} \mathrm{CFUg}^{-1}$ at station III in winter and $640.3 \times 10^{4} \mathrm{CFUg}^{-1}$ at station I in summer. The relative high values of SC were observed in summer season $\left(80.38 \times 10^{4} \mathrm{CFUg}^{-1}\right)$ in station VI, in spring $78.33 \times 10^{4} \mathrm{CFUg}^{-1}$ in station I and others. Moreover, the relative low values of SC were observed in many stations especially during winter season. The total viable count of VC in lake water fluctuated between $0.13 \times 10^{3} \mathrm{CFUg}^{-1}$ at station VII in winter and $35.24 \times 10^{3} \mathrm{CFUg}^{-1}$ at station I in summer. The relative high values of VC were observed in summer season $\left(27.33 \times 10^{3} \mathrm{CFUg}^{-1}\right)$ in station I in summer, while the relative low values of $\mathrm{VC}$ were observed in many stations especially during winter season. The total viable count of AC in lake water ranged between $2.86 \times 10^{2} \mathrm{CFUg}^{-1}$ at station VI in winter and $60.53 \times 10^{2} \mathrm{CFUg}^{-1}$ at station $\mathrm{V}$ in summer. The relative high values of AC were observed in spring season $\left(44.73 \times 10^{2} \mathrm{CFUg}^{-1}\right)$ in station $\mathrm{V}$ and $40.66 \times 10^{2} \mathrm{CFUg}^{-1}$ in station VI in summer. Moreover, the relative low values of AC were observed in many stations especially during winter.

Genotype and phenotype characterization of common isolates habited in Lake Qarun

Sequencing data were aligned against the 16S rRNA sequences of (http://blast.ncbi.nlm.nih.gov/Blast.cgi). Data are shown in Table 3. It has been found that the bacterial isolate 19T showed $97 \%$ sequence homology to Bacillus firmus. It was observed that the sequence of the isolate 22T showed $98 \%$ sequence homology to Bacillus stratosphericus. It has been conducted that the isolate $14 \mathrm{P}$ showed $97 \%$ sequence homology to Exiguobacterium summer. The nitrite $\left(\mathrm{NO}_{2}-\mathrm{N}\right)$ in lake water varied between mexicanum. It has been observed that the isolate $11 \mathrm{~S} 4.10 \mu \mathrm{g} / \mathrm{l}$ at sit IV and $646.5 \mu \mathrm{g} / \mathrm{l}$ at sit I. The relative high showed $97 \%$ sequence homology to Stenotrophomonas rhizophila. It has been found that the isolate $2 \mathrm{~V}$ showed 97\% sequence homology to Halomonas stevensii. It has been detected that the isolate 9S showed $89 \%$ sequence homology to Halomonas korlensis. On the other side, the isolates (19T, 22T, 14P, 11S, 2V, and 9S) were activated on a nutrient agar plate. Moreover, Table 4 shows some phenotypic characteristics of the selected isolates. These included colony and cell morphology, Gram reaction, catalase and oxidase test in addition to some physiological and biochemical experiments.

\section{Physical analysis of lake water}

Physical analyses ( $\mathrm{pH}$, temperature, and salinity) were determined in subsurface water. Data are shown in Table 5. The $\mathrm{pH}$ varied between 7.08 at sit I and 8.73 at sit $\mathrm{V}$. The relative high values of $\mathrm{pH}(8.73)$ were observed in winter in the station $\mathrm{V}$, while the relative low values of $\mathrm{pH}$ were observed in the station I during summer. The temperature varied between $15.6^{\circ} \mathrm{C}$ at sit VIII and $32.2^{\circ} \mathrm{C}$ at sit I. The relative high values of temperature $\left(32.2^{\circ} \mathrm{C}\right)$ were observed in summer in the station I, while the relative low values of temperature were observed in the station VIII during winter. The salinity varied between $3.18 \%$ at sit I and $51.72 \%$ at sit III. The relative high values of salinity (51.72\%) were observed in winter in the station III, while the relative low values of salinity were observed in the station I during summer.

\section{Hydrochemical characterization of lake water}

Some chemical analyses (DO, BOD and COD) were determined in subsurface water of lake. Data are given in Table 6. The dissolved oxygen varied between $3.89 \mathrm{md} / \mathrm{l}$ at sit VI and $8.96 \mathrm{md} / \mathrm{l}$ at sit IV. The relative high values of DO $(8.96 \mathrm{md} / \mathrm{l})$ were observed in winter in the station IV, while the relative low values of $\mathrm{DO}$ were observed in the station VI during autumn. The BOD varied between 1.08 $\mathrm{mg} / \mathrm{l}$ at sit VIII and $6.47 \mathrm{mg} / \mathrm{l}$ at sit IV. The relative high values of BOD $(6.47 \mathrm{mg} / \mathrm{l})$ were observed in winter in the station VI, while the relative low values of BOD were observed in the station $\mathrm{V}$ during autumn. The COD varied between $11.36 \mathrm{mg} / \mathrm{l}$ at sit I and $53.64 \mathrm{mg} / \mathrm{l}$ at sit VIII. The relative high values of COD (53.64 mg/l) were observed in spring in the station VIII, while the relative low values of COD were observed in the station $\mathrm{V}$ during winter.

\section{Nutrients profile of lake water}

The phosphate $\left(\mathrm{PO}_{4}-\mathrm{P}\right)$ in lake water during the period of study (2014 -2015) varied between $1.453 .4 \mu \mathrm{g} / \mathrm{l}$ at sit VIII and $498.4 \mu \mathrm{g} / \mathrm{l}$ at sit I. The relative high values of $\mathrm{PO}_{4-}$ P $(498.4 \mu \mathrm{g} / \mathrm{l})$ were observed in summer in the station VIII, while the relative low values of $\mathrm{PO}_{4}-\mathrm{P}$ were observed in the station I during autumn. The ammonia $\left(\mathrm{NH}_{4}-\mathrm{N}\right)$ in lake water varied between $14.73 \mu \mathrm{g} / \mathrm{l}$ at sit II and $1485 \mu \mathrm{g} / \mathrm{l}$ at sit I. The relative high values of $\mathrm{NH}_{4}-\mathrm{N}(498.4 \mu \mathrm{g} / \mathrm{l})$ were observed in summer in the station I, while the relative low values of $\mathrm{NH}_{4}-\mathrm{N}$ were observed in the station II during 
values of $\mathrm{NO}_{2}-\mathrm{N}(646.5 \mu \mathrm{g} / \mathrm{l})$ were observed in autumn in relative low values of $\mathrm{NO}_{3}-\mathrm{N}$ were observed in the station the station I, while the relative low values of $\mathrm{NO}_{2}-\mathrm{N}$ were III during winter. The silicate $\left(\mathrm{SiO}_{4}\right)$ in lake water varied observed in the station IV during winter. The nitrate $\left(\mathrm{NO}_{3}\right.$ - between $894.6 \mu \mathrm{g} / \mathrm{l}$ at sit VI and $4682 \mu \mathrm{g} / \mathrm{l}$ at sit VII. The $\mathrm{N})$ in lake water varied between $14.79 \mu \mathrm{g} / \mathrm{l}$ at sit III and relative high values of $\mathrm{SiO}_{4}(4682 \mu \mathrm{g} / \mathrm{l})$ were observed in $2138 \mu \mathrm{g} / \mathrm{l}$ at sit I. The relative high values of $\mathrm{NO}_{3}-\mathrm{N}$ (2138 winter in the station I, while the relative low values of $\mathrm{SiO}_{4}$ $\mu \mathrm{g} / \mathrm{l})$ were observed in summer in the station I, while the were observed in the station III during autumn.

Table 1: Regional and seasonal of different bacterial groups in subsurface water samples of Lake Qarun during the period of study (2014 -2015)

\begin{tabular}{|c|c|c|c|c|c|c|c|c|c|c|}
\hline \multirow[t]{2}{*}{ Season } & \multicolumn{9}{|c|}{ TBVCx10 ${ }^{4}$ CFUml $^{-1} /$ Station } & \multirow[b]{2}{*}{ Max. } \\
\hline & I & II & III & IV & $\mathbf{V}$ & VI & VII & VIII & Min. & \\
\hline Autumn & 106.4 & 47.3 & 22.3 & 1.43 & 41.5 & 5.10 & 6.36 & 1.09 & 1.09 & 106.4 \\
\hline Winter & 40.3 & 38.3 & 2.05 & 0.45 & 0.33 & 0.60 & 0.34 & 0.31 & 0.31 & 40.30 \\
\hline Spring & 120.1 & 52.0 & 28.3 & 2.10 & 43.1 & 5.40 & 6.50 & 24.4 & 2.10 & 120.1 \\
\hline Summer & 200.4 & 55.1 & 30.4 & 60.5 & 56.4 & 6.36 & 7.83 & 25.3 & 6.36 & 200.4 \\
\hline \multicolumn{11}{|c|}{ SCx10 $^{4}$ CFUml $^{-1} /$ Station } \\
\hline Autumn & 5.48 & 1.04 & 1.12 & 0.41 & 2.1 & 1.12 & 1.14 & 2.17 & 0.41 & 5.48 \\
\hline Winter & 0.40 & 0.18 & 0.31 & 0.25 & 0.05 & 0.22 & 0.27 & 0.12 & 0.05 & 0.40 \\
\hline Spring & 6.10 & 2.6 & 1.30 & 1.03 & 2.53 & 1.73 & 1.84 & 3.93 & 1.03 & 6.10 \\
\hline Summer & 9.55 & 4.63 & 2.52 & 1.80 & 8.15 & 2.12 & 1.91 & 4.66 & 1.8 & 9.55 \\
\hline \multicolumn{11}{|c|}{ VCx10 $^{3}$ CFUml $^{-1} /$ Station } \\
\hline Autumn & 5.10 & 0.12 & 1.07 & 0.13 & 0.20 & 0.19 & 0.11 & 0.81 & 0.11 & 5.1 \\
\hline Winter & 0.13 & 0.10 & 0.2 & 0.04 & 0.18 & 0.14 & 0.03 & 0.51 & 0.03 & 0.51 \\
\hline Spring & 7.10 & 1.40 & 1.50 & 0.14 & 0.25 & 0.22 & 0.123 & 1.00 & 0.123 & 7.1 \\
\hline Summer & 30.1 & 1.40 & 8.04 & 4.80 & 1.61 & 1.29 & 75.3 & 2.40 & 1.29 & 75.3 \\
\hline \multicolumn{11}{|c|}{$\mathrm{ACx} 10^{2} \mathrm{CFUml}^{-1} /$ Station } \\
\hline Autumn & 14.47 & 7.29 & 24.27 & 20.29 & 10.63 & 17.37 & 9.59 & 22.5 & 7.29 & 24.27 \\
\hline Winter & 12.33 & 5.54 & 21.77 & 17.43 & 8.38 & 14.16 & 7.63 & 20.41 & 5.54 & 21.77 \\
\hline Spring & 16.52 & 13.29 & 26.43 & 22.30 & 12.16 & 20.27 & 10.23 & 30.13 & 10.23 & 30.13 \\
\hline Summer & 22.48 & 18.25 & 45.76 & 30.45 & 15.23 & 36.29 & 12.5 & 60.32 & 12.5 & 60.32 \\
\hline \multicolumn{11}{|c|}{$\mathrm{SFCx}^{5} \mathrm{CFUml}^{-1} /$ Station } \\
\hline Autumn & 12.18 & 2.23 & 2.10 & 1.10 & 2.05 & 3.22 & 8.32 & 1.29 & 1.10 & 12.18 \\
\hline Winter & 1.07 & 1.80 & 0.30 & 0.60 & 0.40 & 1.50 & 0.72 & 0.40 & 0.30 & 1.80 \\
\hline Spring & 13.21 & 3.21 & 3.93 & 1.12 & 2.23 & 3.41 & 12.55 & 1.32 & 1.12 & 13.21 \\
\hline Summer & 56.13 & 3.22 & 29.13 & 3.23 & 20.23 & 18.13 & 50.8 & 1.61 & 1.61 & 56.13 \\
\hline \multicolumn{11}{|c|}{ ECx10 $^{5}$ CFUml $^{-1} /$ Station } \\
\hline Autumn & 8.21 & 0.70 & 2.02 & 1.03 & 0.83 & 0.31 & 7.74 & 0.82 & 0.31 & 8.21 \\
\hline Winter & 0.50 & 0.30 & 1.19 & 0.51 & 0.21 & 0.10 & 2.21 & 0.61 & 0.10 & 2.21 \\
\hline Spring & 23.9 & 1.32 & 3.32 & 1.13 & 1.14 & 0.72 & 7.83 & 1.54 & 0.72 & 23.90 \\
\hline Summer & 90.22 & 2.92 & 32.93 & 1.40 & 3.25 & 0.82 & 12.24 & 1.91 & 0.82 & 90.22 \\
\hline \multicolumn{11}{|c|}{ TCx10 $^{5}$ CFUml $^{-1} /$ Station } \\
\hline Autumn & 24.63 & 4.21 & 4.33 & 1.32 & 2.81 & 4.12 & 9.21 & 2.33 & 1.32 & 24.63 \\
\hline Winter & 1.59 & 3.31 & 1.91 & 1.72 & 1.41 & 2.31 & 5.54 & 2.12 & 1.41 & 5.54 \\
\hline Spring & 89.17 & 5.12 & 5.42 & 3.21 & 2.91 & 4.12 & 16.63 & 3.32 & 2.91 & 89.17 \\
\hline Summer & 100.1 & 6.63 & 49.9 & 3.83 & 3.83 & 5.04 & 126.0 & 4.50 & 3.83 & 126.0 \\
\hline
\end{tabular}


Table 2: Regional and seasonal of different bacterial groups in sediment samples of Lake Qarun during the period of study (2014 -2015)

\begin{tabular}{|c|c|c|c|c|c|c|c|c|c|c|}
\hline \multirow[t]{2}{*}{ Season } & \multicolumn{9}{|c|}{ TBVCx10 $^{5} \mathrm{CFUg}^{-1} /$ Station } & \multirow[b]{2}{*}{ Max. } \\
\hline & I & II & III & IV & $\mathbf{V}$ & VI & VII & VIII & Min. & \\
\hline Autumn & 3.72 & 1.82 & 11.05 & 14.06 & 2.80 & 3.81 & 3.22 & 4.11 & 1.82 & 14.06 \\
\hline Winter & 3.62 & 0.82 & 2.43 & 1.63 & 1.13 & 1.83 & 0.15 & 3.81 & 0.15 & 3.81 \\
\hline Spring & 10.03 & 2.33 & 11.20 & 14.16 & 3.33 & 5.53 & 8.27 & 4.51 & 2.33 & 14.16 \\
\hline Summer & 60.49 & 3.82 & 12.83 & 14.53 & 8.41 & 40.04 & 11.89 & 24.09 & 3.82 & 60.49 \\
\hline \multicolumn{11}{|c|}{ SCx10 $^{4} \mathrm{CFUg}^{-1} /$ Station } \\
\hline Autumn & 50.14 & 7.52 & 8.11 & 3.14 & 15.7 & 8.21 & 10.15 & 3.32 & 3.14 & 50.14 \\
\hline Winter & 40.13 & 2.73 & 1.74 & 4.05 & 11.31 & 7.51 & 8.62 & 2.84 & 1.74 & 40.13 \\
\hline Spring & 78.33 & 40.14 & 20.42 & 6.24 & 21.36 & 38.28 & 14.46 & 4.06 & 4.06 & 78.33 \\
\hline Summer & 640.3 & 63.25 & 33.06 & 18.3 & 40.54 & 80.38 & 27.34 & 44.03 & 18.3 & 640.3 \\
\hline \multicolumn{11}{|c|}{$\mathrm{VCx}^{3} \mathrm{CFUg}^{-1} /$ Station } \\
\hline Autumn & 0.82 & 0.40 & 8.09 & 0.55 & 0.38 & 0.53 & 0.16 & 0.18 & 0.16 & 8.09 \\
\hline Winter & 0.73 & 0.32 & 7.41 & 0.42 & 0.26 & 0.43 & 0.13 & 0.15 & 0.13 & 7.41 \\
\hline Spring & 27.33 & 6.02 & 8.26 & 0.71 & 1.63 & 3.36 & 0.63 & 19.16 & 0.63 & 27.33 \\
\hline Summer & 35.24 & 15.05 & 9.42 & 0.83 & 1.82 & 3.53 & 0.84 & 20.02 & 0.83 & 35.24 \\
\hline \multicolumn{11}{|c|}{$\mathrm{ACx}^{2}{ }^{2} \mathrm{CFUg}^{-1} /$ Station } \\
\hline Autumn & 11.32 & 9.33 & 14.12 & 8.40 & 30.62 & 21.10 & 17.50 & 38.13 & 8.40 & 38.13 \\
\hline Winter & 9.17 & 4.21 & 10.86 & 2.86 & 16.31 & 10.21 & 8.27 & 19.47 & 2.86 & 19.47 \\
\hline Spring & 13.6 & 10.4 & 15.8 & 15.9 & 44.73 & 25.6 & 20.3 & 39.3 & 10.4 & 44.73 \\
\hline Summer & 17.57 & 21.28 & 18.21 & 20.4 & 60.53 & 40.66 & 34.3 & 51.76 & 17.57 & 60.53 \\
\hline
\end{tabular}

Table 3: Accession number of the experimental 16S rRNA sequence and similarity percentage to the closest known species

\begin{tabular}{|c|c|c|c|}
\hline $\begin{array}{c}\text { Isolate } \\
\text { code }\end{array}$ & Accession no. & $\begin{array}{l}\text { Most related } \\
\text { Species }\end{array}$ & $\begin{array}{c}\text { Similarity }^{1} \\
(\%)\end{array}$ \\
\hline $19 \mathrm{~T}$ & NR_112615-1 & Bacillus firmus strain NBRC 15306 & 97 \\
\hline $22 \mathrm{~T}$ & NR_118441-1 & Bacillus stratosphericus strain $41 K F 2 a$ & 98 \\
\hline $14 \mathrm{P}$ & $\overline{\text { NR_042424-1 }}$ & Exiguobacterium mexicanum strain $8 N$ & 97 \\
\hline $11 S$ & NR_028930-1 & Stenotrophomonas rhizophila strain e-p10 & 97 \\
\hline $2 \mathrm{~V}$ & $\overline{\text { NR_115088-1 }}$ & Halomonas stevensii strain S18214 & 97 \\
\hline 9S & NR_044397-1 & Halomonas korlensis strain XK1 & 89 \\
\hline
\end{tabular}

${ }^{1}$ Aligned ribosomal DNA fragments were obtained by PCR using primers F27 and R149. 


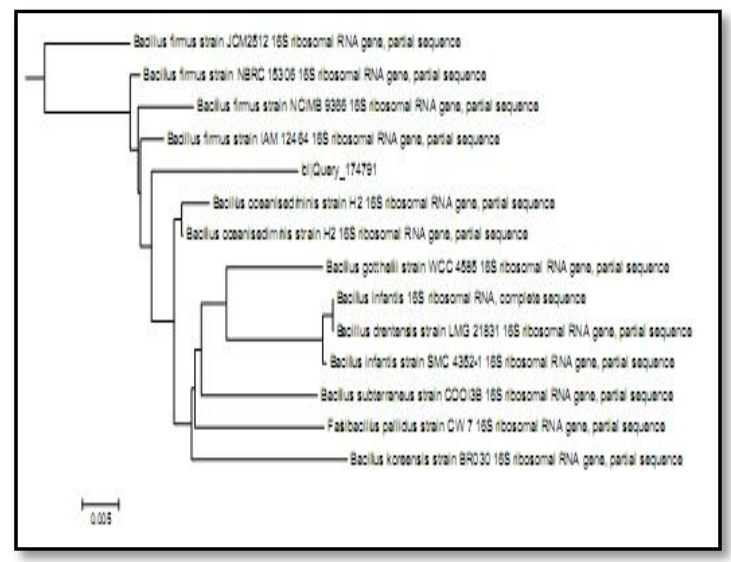

Bacillus firmus strain NBRC 15306

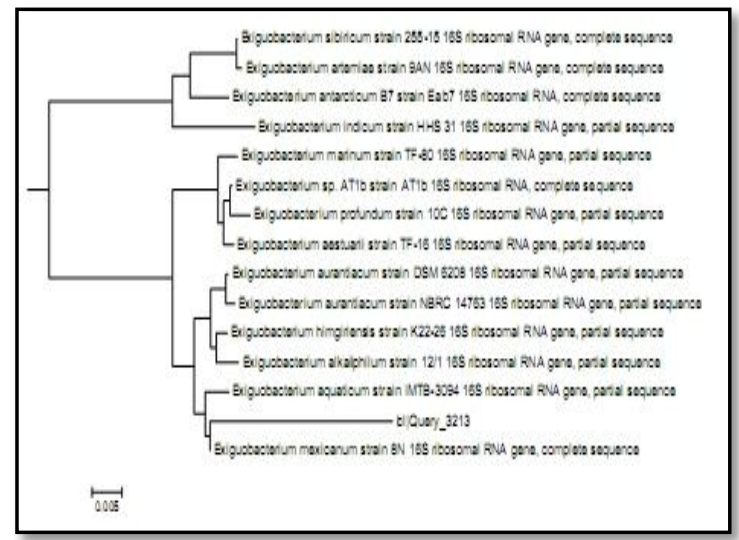

xiguobacterium mexicanum strain $8 \mathrm{~N}$

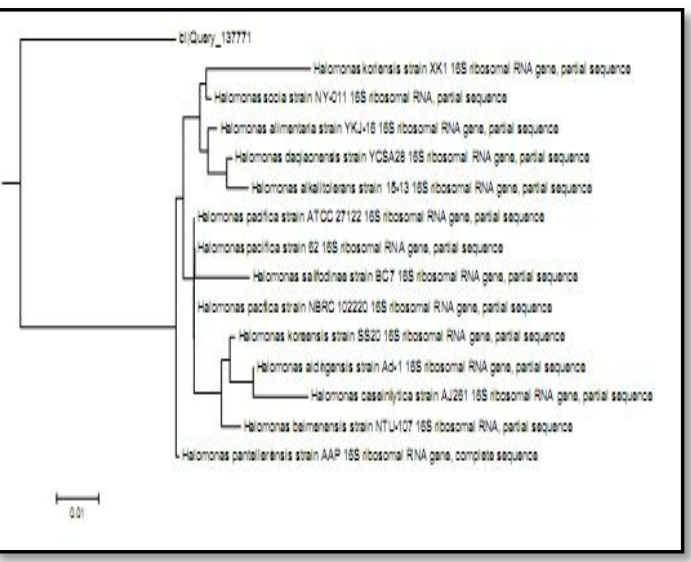

Bacillus stratosphericus strain 41 KF2a

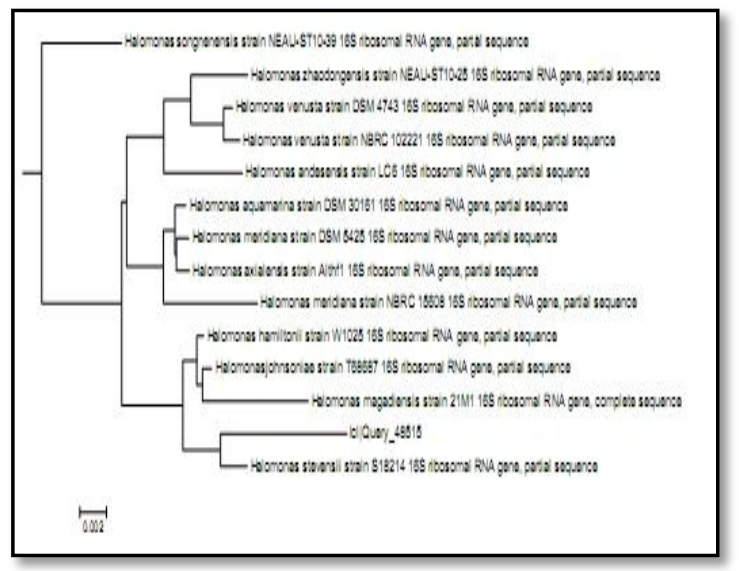

Halomonas stevensii strain S18214

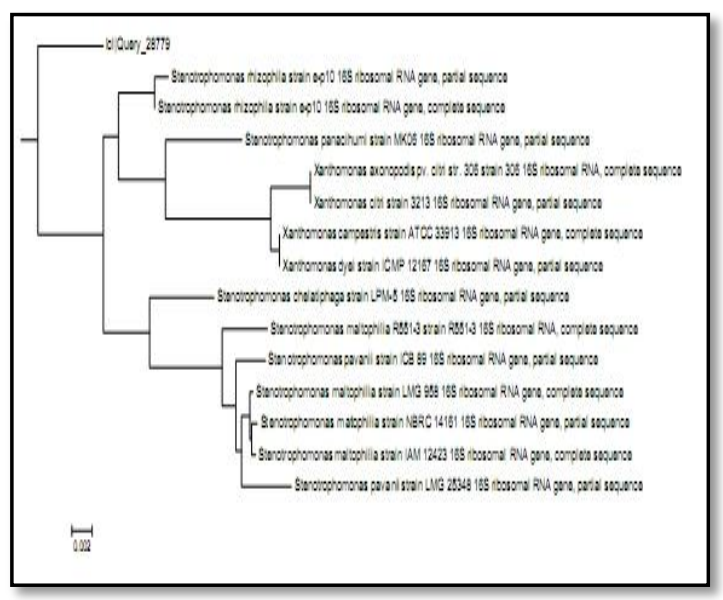

Stenotrophomonas rhizophila strain e-p10

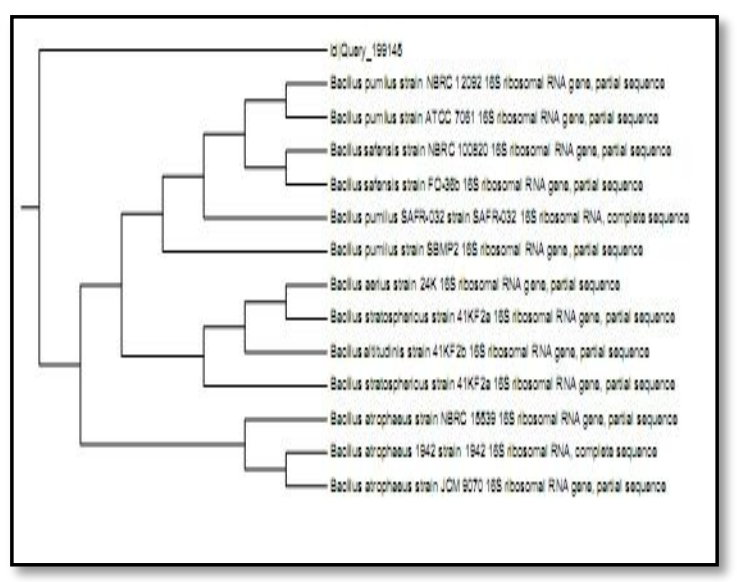

Halomonas korlensis strain XK1

Figure 2: Phylogenetic analysis of six bacterial isolates as common based on partial sequencing of $16 \mathrm{~S}$ rRNA 
Table 5: Phenotypic characterization of the most common bacterial isolates

\begin{tabular}{|c|c|c|c|c|c|c|}
\hline \multirow[t]{2}{*}{ Test } & \multicolumn{6}{|c|}{ Result } \\
\hline & $2 \mathrm{~V}$ & 9S & 19T & $22 \mathrm{~T}$ & 14P & 11S \\
\hline Gram reaction & -ve & -ve & + ve & + ve & + ve & + ve \\
\hline Colony color & Cream & Orange & Cream & White & Orange & Yellow \\
\hline Motile & Motile & Non-motile & Motile & Motile & Motile & Motile \\
\hline Temperature & $30-35^{\circ} \mathrm{C}$ & $4.0-43^{\circ} \mathrm{C}$ & $25-42^{\circ} \mathrm{C}$ & $8-37^{\circ} \mathrm{C}$ & $10-30^{\circ} \mathrm{C}$ & $4-37^{\circ} \mathrm{C}$ \\
\hline $\mathrm{pH}$ & $8-9$ & $8.5-9.0$ & $4-10$ & $6-10$ & $6-10$ & $6-12$ \\
\hline $\mathrm{NaCl} \%$ & $3-7.5 \%$ & $6-10 \%$ & $2-7 \%$ & $0-10 \%$ & $1-7 \%$ & Up to 4.5 \\
\hline Catalase & +ve & +ve & +ve & +ve & +ve & -ve \\
\hline Oxidase & +ve & +ve & +ve & +ve & -ve & +ve \\
\hline Nitrate reduction & -ve & -ve & +ve & +ve & +ve & -ve \\
\hline Methyl red test & -ve & +ve & +ve & -ve & -ve & +ve \\
\hline Voges proskaur test & -ve & -ve & -ve & +ve & +ve & -ve \\
\hline Citrate test & +ve & -ve & -ve & -ve & +ve & +ve \\
\hline $\mathrm{H}_{2} \mathrm{~S}$ production test & -ve & -ve & -ve & -ve & -ve & +ve \\
\hline Glucose utilization & +ve & +ve & -ve & +ve & +ve & +ve \\
\hline Lysinedecarboxylase test & -ve & -ve & -ve & -ve & +ve & -ve \\
\hline Urease & +ve & +ve & -ve & +ve & -ve & -ve \\
\hline
\end{tabular}

Table 6: Regional and seasonal of physical parameters in Lake Qarun water during the period of study (2014-2015)

\begin{tabular}{|c|c|c|c|c|c|c|c|c|c|c|}
\hline \multirow{2}{*}{ Season } & \multicolumn{10}{|c|}{ pH/Station } \\
\hline & $\mathbf{I}$ & II & III & IV & & VI & VII & VIII & Min. & Max. \\
\hline Autumn & 7.97 & 8.19 & 8.29 & 8.20 & 8.29 & 8.30 & 8.30 & 8.41 & 7.97 & 8.41 \\
\hline Winter & 7.79 & 8.35 & 8.41 & 8.51 & 8.73 & 8.49 & 8.20 & 8.05 & 7.79 & 8.73 \\
\hline Spring & 7.29 & 8.32 & 8.21 & 8.17 & 8.28 & 8.35 & 8.19 & 8.29 & 7.29 & 8.35 \\
\hline Summer & 7.08 & 8.35 & 8.13 & 8.23 & 8.28 & 8.37 & 8.23 & 8.32 & 7.08 & 8.37 \\
\hline \multicolumn{11}{|c|}{ Temperature $\left({ }^{0} \mathrm{C}\right) /$ Station } \\
\hline Autumn & 21.5 & 21.4 & 21.1 & 21.1 & 21.1 & 21.2 & 21.4 & 21.0 & 21.0 & 21.5 \\
\hline Winter & 16.8 & 16.2 & 15.7 & 15.8 & 15.7 & 15.8 & 16.1 & 15.6 & 15.6 & 16.8 \\
\hline Spring & 26.5 & 26.3 & 26.1 & 26.1 & 26.1 & 26.1 & 26.2 & 26.0 & 26.0 & 26.5 \\
\hline Summer & 32.2 & 32.0 & 31.5 & 31.6 & 31.6 & 31.8 & 31.9 & 31.5 & 31.5 & 32.2 \\
\hline \multicolumn{11}{|c|}{ Salinity $(\%) /$ Station } \\
\hline Autumn & 5.27 & 15.04 & 23.84 & 28.85 & 29.22 & 29.35 & 24.62 & 30.04 & 5.27 & 30.04 \\
\hline Winter & 3.97 & 49.80 & 51.72 & 32.04 & 40.52 & 35.64 & 35.97 & 37.65 & 3.97 & 51.72 \\
\hline Spring & 3.18 & 27.18 & 26.22 & 29.13 & 34.13 & 32.32 & 34.57 & 34.88 & 3.18 & 34.88 \\
\hline Summer & 2.26 & 28.51 & 29.30 & 30.71 & 33.60 & 32.27 & 33.26 & 34.51 & 2.26 & 34.51 \\
\hline
\end{tabular}

Table 7: Regional and seasonal of some chemical parameters in Lake Qarun water during the period of study (2014-2015)

\begin{tabular}{|c|c|c|c|c|c|c|c|c|c|c|}
\hline \multirow[t]{2}{*}{ Season } & \multicolumn{10}{|c|}{ DO (md/l)/Station } \\
\hline & $\mathbf{I}$ & II & III & IV & $\mathbf{V}$ & VI & VII & VIII & Min. & Max. \\
\hline Autumn & 4.53 & 8.74 & 5.18 & 6.15 & 3.91 & 3.89 & 7.13 & 3.90 & 3.89 & 8.74 \\
\hline Winter & 4.97 & 5.89 & 6.56 & 8.96 & 8.42 & 7.98 & 7.45 & 8.62 & 4.97 & 8.96 \\
\hline Spring & 4.17 & 6.51 & 6.74 & 7.80 & 7.35 & 6.04 & 5.84 & 6.09 & 4.17 & 7.80 \\
\hline Summer & 4.36 & 6.30 & 6.68 & 7.63 & 6.81 & 6.22 & 5.98 & 6.18 & 4.36 & 7.63 \\
\hline \multicolumn{11}{|c|}{ BOD (mg/l)/Station } \\
\hline Autumn & 1.77 & 3.32 & 2.61 & 3.29 & 1.08 & 1.17 & 3.50 & 1.40 & 1.08 & 3.50 \\
\hline Winter & 4.2 & 3.23 & 5.24 & 5.84 & 6.11 & 6.47 & 5.17 & 6.34 & 3.23 & 6.47 \\
\hline Spring & 3.24 & 2.16 & 3.86 & 4.89 & 3.83 & 3.94 & 2.51 & 3.36 & 2.16 & 4.89 \\
\hline Summer & 2.15 & 2.12 & 3.53 & 4.35 & 3.66 & 3.81 & 2.32 & 3.23 & 2.12 & 4.35 \\
\hline \multicolumn{11}{|c|}{ COD (mg/l)/Station } \\
\hline Autumn & 25.65 & 30.16 & 32.91 & 35.42 & 33.83 & 47.88 & 50.00 & 52.19 & 25.65 & 52.19 \\
\hline Winter & 11.36 & 21.02 & 18.48 & 17.66 & 20.68 & 21.18 & 19.83 & 16.87 & 11.36 & 21.18 \\
\hline Spring & 30.48 & 37.33 & 40.56 & 38.63 & 36.65 & 51.66 & 49.39 & 53.64 & 30.48 & 53.64 \\
\hline Summer & 36.36 & 39.29 & 45.67 & 42.82 & 40.27 & 42.11 & 43.58 & 41.25 & 36.36 & 45.67 \\
\hline
\end{tabular}


Table 8: Regional and seasonal of nutrients $(\mu \mathrm{g} / \mathrm{l})$ in Lake Qarun water during the period of study (20142015)

\begin{tabular}{|c|c|c|c|c|c|c|c|c|c|c|}
\hline \multirow[t]{2}{*}{ Season } & \multicolumn{10}{|c|}{$\mathrm{PO}_{4}-\mathrm{P}(\mu \mathrm{g} / \mathrm{l}) /$ Station } \\
\hline & $\mathrm{I}$ & II & III & IV & $\mathrm{V}$ & VI & VII & VIII & Min. & Max. \\
\hline Autumn & 396.8 & 112.7 & 29.65 & 15.5 & 16.84 & 5.166 & 11.7 & 1.453 & 1.453 & 396.8 \\
\hline Winter & 398.6 & 96.72 & 124.4 & 107.9 & 99.93 & 97.76 & 162.6 & 113.3 & 96.72 & 398.6 \\
\hline Spring & 415.3 & 152.7 & 132.0 & 136.5 & 105.8 & 207.2 & 172.7 & 122.6 & 105.8 & 415.3 \\
\hline Summer & 498.4 & 146.4 & 141.6 & 157.8 & 134.4 & 144.4 & 143.2 & 148.5 & 134.4 & 498.4 \\
\hline \multicolumn{11}{|c|}{$\mathrm{NH}_{4}-\mathrm{N}(\mu \mathrm{g} / \mathrm{l}) /$ Station } \\
\hline Autumn & 460.2 & 15.02 & 26.08 & 32.29 & 214.1 & 98.56 & 174.7 & 123.6 & 15.02 & 460.2 \\
\hline Winter & 954.3 & 40.46 & 23.1 & 21.74 & 25.62 & 58.1 & 42.42 & 43.26 & 21.74 & 954.3 \\
\hline Spring & 1349 & 23.47 & 22.04 & 19.49 & 200.4 & 116.1 & 203.0 & 114.2 & 19.49 & 1349 \\
\hline Summer & 1485 & 14.73 & 26.22 & 32.82 & 218.6 & 96.57 & 178.6 & 124 & 14.73 & 1485 \\
\hline \multicolumn{11}{|c|}{$\mathrm{NO}_{2}-\mathrm{N}(\mu \mathrm{g} / \mathrm{l}) /$ Station } \\
\hline Autumn & 646.5 & 139.2 & 52.93 & 29.77 & 5.55 & 13.62 & 41.67 & 18.85 & 5.553 & 646.5 \\
\hline Winter & 101.0 & 5.92 & 8.4 & 4.10 & 9.19 & 17.5 & 29.02 & 19.74 & 4.10 & 101.0 \\
\hline Spring & 114.2 & 76.42 & 35.51 & 40.70 & 30.78 & 57.59 & 63.88 & 39.05 & 30.78 & 114.2 \\
\hline Summer & 127.7 & 56.56 & 45.22 & 44.29 & 43.2 & 43.61 & 47.06 & 46.62 & 43.2 & 127.7 \\
\hline \multicolumn{11}{|c|}{$\mathrm{NO}_{3}-\mathrm{N}(\mu \mathrm{g} / \mathrm{l}) /$ Station } \\
\hline Autumn & 1271 & 1122 & 317.4 & 335.1 & 71.2 & 74.18 & 647.8 & 139.6 & 71.2 & 1271 \\
\hline Winter & 165.8 & 31.36 & 14.79 & 16.05 & 30.8 & 34.26 & 86.19 & 108.9 & 14.79 & 165.8 \\
\hline Spring & 2038 & 161.8 & 73.10 & 85.42 & 62.70 & 78.71 & 96.97 & 74.85 & 62.70 & 2038 \\
\hline Summer & 2138 & 139.7 & 83.77 & 93.10 & 68.40 & 72.55 & 85.33 & 80.37 & 68.40 & 2138 \\
\hline \multicolumn{11}{|c|}{$\mathrm{SiO}_{4}(\mu \mathrm{g} / \mathrm{l}) /$ Station } \\
\hline Autumn & 1121 & 1086 & 1078 & 1012 & 1317 & 894.6 & 1502 & 917.0 & 894.6 & 1502 \\
\hline Winter & 4191 & 2810 & 2379 & 2707 & 3213 & 2743 & 4682 & 2052 & 2052 & 4682 \\
\hline Spring & 2246 & 3981 & 3549 & 2317 & 3081 & 3568 & 2319 & 1980 & 1980 & 3981 \\
\hline Summer & 2754 & 4289 & 3415 & 2218 & 3623 & 3444 & 2484 & 3483 & 2218 & 4289 \\
\hline
\end{tabular}

\section{Discussion}

Bacteriological characteristics of Lake Qarun

Microbial pollution is one of the most dangerous types of water pollutants, as it leads to the spread of many diseases such as cholera, typhoid and severe diarrhea and hepatitis. Therefore, attention must be paid to monitoring microbial contamination in the Egyptian lakes, especially Lake Qarun, where is considered the key to development in the province of Fayoum, to a source of fisheries and salts. On the other side, international standards and health risk criteria of water resources based on indicator bacteria. European Commission Guide Standard 1998 and Ministry of Health, Egypt (1996) accepted the guide values of 500/100 ml water for coliform bacteria and $100 / 100 \mathrm{ml}$ water for each fecal coliform and fecal Streptococci. In lake fisheries, the Egyptian standard accepted 70/100 $\mathrm{ml}$ water of the lake for total coliform bacteria and $5000 / 100 \mathrm{ml}$ for drainage water. Interpretation of the indicator bacteria during the period of study (20142015) in Lake Qarun was objected to the Egyptian Guide Standard (Ministry of Health, Egypt, 1996). The use of fecal indicator bacteria of sewage (total coliform and fecal $S$. feacalis and E. coli), which are used locally and internationally as a measure of the quality of water in order to protect the water from pollution and the preservation of human health, as well as, fisheries. This may because the existence of these bacteria are considered excellent index on the possibility of the presence of other bacteria causing serious diseases. 
By judging the hygienic water quality, the indicator bacteria in Lake Qarun subsurface waters exceeded the acceptable values in the following stations along the period of study:

1. The lowest count of $S$. feacalis was detected in station III in winter, while the highest was determined in station I in summer. The relative high values were observed in summer season in station VII, while the relative low values were observed in many stations especially during winter season.

2. The lowest count of $E$. coli was recorded in station VI in winter, while the highest was estimated in station I in summer. The relative high values were observed in summer season in station III, while the relative low values were observed in many stations especially during winter season.

3. The lowest count of total coliform sp. was detected in station IV in autumn, while the highest count was conducted in station VII in summer. The relative high values were observed in summer season and in spring in station I, while the relative low values were observed in many stations especially during winter season.

4. The values of these indicators were not exceeded than the acceptable values according to Egyptian Guide Standard \& European Commission Guide Standard.

As well as, the relative low values were observed in many stations especially during winter season. The lowest count of bacteria during the period of study was of Aeromonas sp.in sediment in winter in station IV. On the other side, the highest count of bacteria during the same period was of TBVC in sediment in summer in station I. The most affected station was I (front of the Bank of Bats), and the most affected season was summer.

However, some studies have been conducted on the microbiological properties of Lake Qarun included; Sabae (1993) studied the microbiological properties of the waters of Lake Qarun by studying the total number of bacteria at a temperature of $22^{\circ} \mathrm{C}$ (saprophytic bacteria) and $37^{\circ} \mathrm{C}$ (pathogenic bacteria), as well as, fecal indicator bacteria of sewage (total coliform and fecal $S$. feacalis and E. coli). The study also included the distribution of bacteria own cycle of nitrogen and bacteria degrading cellulose. The study showed that the lake has not yet reached dangerous phase of the pollution affecting the biodiversity. In addition, Sabae (1996) monitored the microbiological properties of the layers of the bottom of the lake by studying the total bacterial number at a temperature of $22^{\circ} \mathrm{C}$ (saprophytic bacteria) and $37^{\circ} \mathrm{C}$ (pathogenic bacteria), as well as, fecal indicator bacteria of sewage (total coliform and fecal $S$. feacalis and E. coli), as well as the distribution of bacteria reducing sulphate bacteria degrading cellulose. The study showed that the Lake Qarun from the rich lakes in the numbers of bacteria up to $10^{12} \mathrm{CFU} / \mathrm{ml}$, as the bacteria are used as food for plankton which is the main food for the fish. Sabae and Rabeh (2000) declared that the total number of bacteria in the Lake Qarun water ranges between $0.3 \times 11^{10}$ and $93.9 \times 11^{10} \mathrm{CFUml}^{-1}$ at a temperature of $22^{\circ} \mathrm{C}$ and between $0.1 \times 10^{11}$ and $71 \times 10^{11} \mathrm{CFUml}^{-1}$ at $37^{\circ} \mathrm{C}$.

As well as, the study showed that feacal indicator bacteria decreased as we head west of the lake away from the banks. Sabae and Ali (2004) explained that the total number of bacteria in the Lake Qarun water ranges from $2 \times 10^{11}$ and $115 \times 10^{11} \mathrm{CFUml}^{-1}$ at a temperature of $22^{\circ} \mathrm{C}$ and between $2 \times 10^{11}$ and $110 \times 10^{11} \mathrm{CFUml}^{-1}$ at $37^{\circ} \mathrm{C}$. On the other side, the study has shown that distribution of bacteria responsible for cycle nitrogen in the lake is changing through the different seasons, depending on the changing physical and chemical characteristics of the waters of the lake. Ali et al. (2008) monitored that the total number of bacteria in the waters of Lake Qarun ranges from $10^{3} \mathrm{CFUml}^{-1}$ in the center of the lake and between $10^{7} \mathrm{cfu} / \mathrm{ml}$ near the beach. They, also, pointed to fecal indicator bacteria of sewage increased as we head hand lake beach. Abou El-Gheit et al. (2012) have studied the physical and chemical properties and in Lake Qarun and the impact on pathogenic bacteria in fish, as well as, histopathological changes associated with this bacterial diseases in the lake fish. Sabae and Mohamed (2015) have studied the environmental pollution in the Lake Qarun. The study also addressed such impact on tilapia fish from the physiological and histopathological. They found that there were some histopathological changes in the liver, muscle and kidney, in addition to an increase in liver enzyme activity and an increase in glucose, protein and cholesterol level in the blood. Also, a severe shortage at the level of protein in muscles was observed.

On the other hand, the characterization of common bacterial isolates habited in Lake Qarun was achieved using genotypic and phenotypic means. Six bacterial isolates coded; 19T, 22T, 14P, 11S, 2V, and $9 \mathrm{~S}$ were identical counterpart with respect to its $16 \mathrm{~S}$ rRNA sequence. They were identified as; Bacillus firmus strain NBRC 15306, Bacillus stratosphericus strain $41 K F 2 a$, Exiguobacterium mexicanum strain $8 N$, Stenotrophomonas rhizophila strain e-p10, 
Halomonas stevensii strain S18214, and Halomonas korlensis strain XK1, respectively. Bacillus firmus is a species of bacteria within the genus Bacillus. Some strains of this species are very alkaline-tolerant and may grow in environments with $\mathrm{pH}$ as high as 11 (Guffanti et al., 1980). Bacillus stratosphericus is a gram-positive, motile, rod-shaped bacteria t. Based on characteristics such as being endospore-forming, catalase-positive bacteria. López-Cortés et al. (2006) isolated Exiguobacterium mexicanum Gram-positive strain from cysts of the brine shrimp Artemia franciscana. It was subjected to a polyphasic taxonomic analysis. Based on 16S rRNA gene sequence comparison and composition of isoprenoid quinones, peptidoglycan and fatty acids, these organisms are members of the genus Exiguobacterium. Both strains showed 95.9\% 16S rRNA gene sequence similarity to one another.

In addition, Chaturvedi et al. (2005) isolated a novel psychrophilic bacterium, designated strain DVS 3YT, from a moraine sample from the McMurdo Dry Valleys, Antarctica. Phenotypic and chemotaxonomic characteristics and data from a phylogenetic analysis based on 16S rRNA gene sequences indicated that strain DVS 3YT was related to the genus Exiguobacterium. Wolf et al. (2002) studied a polyphasic taxonomic 16 Stenotrophomonas strains from environmental sources. The defining characteristics of the new species were as follows: growth at 4 degrees $\mathrm{C}$ and the absence of growth at $40^{\circ} \mathrm{C}$; the utilization of xylose as a carbon source; lower osmolytic tolerance $(<4.5 \% \mathrm{NaCl}, \mathrm{w} / \mathrm{v})$, although the isolates can produce trehalose and glucosylglycerol as osmoprotective substances; the absence of lipase and beta-glucosidase production; and antifungal activity against plant-pathogenic fungi. They showed a mean similarity of $99.5 \%$ within the cluster. The family Halomonadaceae of the class Gammaproteobacteria currently comprises ten genera, Carnimonas, Chromohalobacter, Cobetia, Halomonas, Halotalea, Kushneria, Modicisalibacter, Salicola, Salinicola and Zymobacter, which accommodate halophilic/halotolerant and non-halophilic bacteria. Since the family Halomonadaceae was first described (Franzmann et al., 1988), its members typically have occurred in saline lakes, solar salt facilities, saline soils and marine environments. Since some of its members are also alkaliphilic, they are found in soda lakes and alkaline soils. The exceptions to the above are Carnimonas nigrificans, Chromohalobacter beijerinckii, Chromohalobacter Chromohalobacter japonicus, alimentaria, Halomonas alkaliphila, Halomonas campaniensis, Halomonas daqingensis, Halomonas desiderata, Halomonas halodenitrificans, Halomonas muralis, Halotalea alkalilenta, Kushneria aurantia, Kushneria avicenniae, Modicisalibacter tunisiensis and Zymobacter palmae (Arahal and Ventosa, 2006; Ben Ali Gam et al., 2007; Ntougias et al., 2007; Peconek et al., 2006; Romano et al., 2005,SanchezPorro et al., 2009; Wu et al., 2008). Lim et al. (2004) isolated a moderately halophilic bacterium, strain SS20(T), capable of growing at salinities of $1-20 \%$ $(\mathrm{w} / \mathrm{v}) \mathrm{NaCl}$ from a solar saltern of the Dangjin area in Korea and characterized taxonomically. Kim et al. (2013) confirmed that Halomonas has been organized as a genus since 1980, and comprises halophilic and/or halotolerant Gram-negative aerobic bacteria, typically found in saline environments.

\section{Hydrochemical characteristics of Lake Qarun}

The values of $\mathrm{pH}$ measured are still lying on the alkaline side. In the present study the $\mathrm{pH}$ in Lake Qarun water varied between 7.08 at sit I and 8.73 at sit $\mathrm{V}$ with general average in the lake 8.45. However, the ideal $\mathrm{pH}$ level for fish growth lies in the range of 6.5-8.0, while the level lower than 4 and higher than 11 is toxic for most of fishes (Delince, 1992). Generally, the $\mathrm{pH}$ values were on the alkaline side and no significant difference was observed between the surface and near bottom water layer. Changes in $\mathrm{pH}$ values are mainly attributed to photosynthesis activities of phytoplankton, aquatic plants, respiration and variations in temperature. Hydrogen ion concentration plays an important role in many of the life processes. Living organisms are very dependent on, and sensitive to the $\mathrm{pH}$. Not only is the hydrogen ion a potential pollution in itself, but it is also related intimately to the concentration of many other substances, particularly the weakly dissociated acids and bases (Delince, 1992). The temperature varied between $15.6^{\circ} \mathrm{C}$ in station VIII and $32.2^{\circ} \mathrm{C}$ in station I. The relative high values of temperature $\left(32.2^{\circ} \mathrm{C}\right.$ ) were observed in (summer season), while the relative low values of temperature were observed in winter. This is in agreement with the results obtained by Rabeh, (2012). The air temperatures ranged on averages between $15.4^{\circ} \mathrm{C}$ during winter and $31^{\circ} \mathrm{C}$ during summer with an annual amplitude of $15.6^{\circ} \mathrm{C}$. The life process of all aquatic microorganisms is affected by water temperature which enhances their active proliferations, so $15.6^{\circ} \mathrm{C}$ amplitude in water temperature of Lake Qarun might be translated into high TVBCs during summer. Temperature is an important physical factor influencing the growth of microorganisms, the annual seawater temperature 
cycle is directly affected by solar radiation and seasonal change in air temperature. The maximum water temperature in summer is a result of the solar heating with a relatively longer day-time in summer than that in winter. The rapid decrease and increase of water temperature occurs in autumn and spring. Water temperature are subjected to considerable variations, due to several factors, such as air temperature, latitudes, sun, seasons, wind action, depth of water, waves and gain or loss of heat in shallow waters close to lands (Delince, 1992). The effect of domestic sewage throughout the year mainly affects the upper $5 \mathrm{~m}$ layer where the surface water salinity may decrease specially in summer and autumn. The minimum surface salinity $(3.18 \%)$ was observed during summer at station $I$ and the maximum one $(51.72 \%$ ) was found in winter season at station III. The increased of human activities, action of winds and the discharge of sewage wastes and their distribution into the sea water is mostly responsible for the decrease in surface water salinity in spring and summer seasons (APAH, 1995).

\section{Dissolved oxygen (DO)}

The presence of oxygen dissolved in water is influenced by photosynthesis and respiration and gas exchange between the air and the surface of the water rates (Krom et al., 1989; Erez et al., 1990). Oxygen content of water depends on a number of physical, chemical, biological and microbiological processes. The deficiency in DO is an important indicator of pollution in a natural water body, describing its biological state, the predominant processes occurring in it, the destruction of organic substances and the intensity of self-purification, Grasshoff (1975) and Dyrssen and Wedborg (1980). The amount of DO was fluctuated between $3.89 \mathrm{mg} / \mathrm{l}$ at sit VI and $8.96 \mathrm{mg} / \mathrm{l}$ at sit IV. Generally, The deficiency of DO values in summer are related mainly to the increase in the rate of oxygen consumption through decomposition of organic matter supplemented by the rise of water temperature Abdel-Halim and Khairy (2007).

\section{Biochemical oxygen demand (BOD)}

It is the amount of dissolved oxygen needed by aerobic biological organisms to break down organic material present in a given water sample at certain temperature over a specific time period. The BOD value is most commonly expressed in milligrams of oxygen consumed per liter of sample during 5 days of incubation at $20^{\circ} \mathrm{C}$ and is often used as a surrogate of the degree of organic pollution of water. BOD can be used as a gauge of the effectiveness of wastewater treatment plants. It is listed as a conventional pollutant in the U.S. Clean Water Act. BOD is similar in function to COD, in that both measure the amount of organic compounds in water. However, COD is less specific, since it measures everything that can be chemically oxidized, rather than just levels of biodegradable organic matter. The BOD in lake water varied between $1.08 \mathrm{mg} / \mathrm{l}$ at sit VIII and $6.47 \mathrm{mg} / \mathrm{l}$ at sit IV. The relative high values of BOD were observed in winter in the station VI, while the relative low values of BOD were observed in the station $\mathrm{V}$ during autumn season. Anon, (1975) pointed to the greater the value of the consumer oxygen was vital evidence of water contamination. He explained that the water containing the values of the oxygen consumed vital less than (1) is the water completely pure and (1-3) are considered pure to some extent and when this value up to (5) water pollution begins. APAH, (1995) flats water containing a quantity of vital oxygen consumed less than (1) the pure waters ; the containing of (2-8) as a moderate water pollution.

\section{Chemical oxygen demand (COD)}

Most applications of COD determine the amount of organic pollutants found in surface water (e.g. lakes and rivers) or wastewater, making COD a useful measure of water quality. It is expressed in milligrams per liter (mg/l), which indicates the mass of oxygen consumed per liter of solution (Tayel et al., 1996). Many governments impose strict regulations regarding the maximum chemical oxygen demand allowed in waste water before they can be returned to the environment. For example, in Switzerland, a maximum oxygen demand between 200 and $1000 \mathrm{mg} / \mathrm{l}$ must be reached before waste water or industrial water can be returned to the environment. Value of consumed oxygen explains chemically the amount of oxygen necessary to oxidize the organic matter present in the water and turn it into carbon dioxide and water (Tayel et al., 1996). Water containing chemically oxygen consumed less than 12 $\mathrm{mg} / \mathrm{L}$ is considered high quality water (Berg, 1942). The COD in lake water varied between $11.36 \mathrm{mg} / \mathrm{l}$ at sit I and $53.64 \mathrm{mg} / \mathrm{l}$ at sit VIII. The relative high values of COD (53.64 mg/l) were observed in spring.

\section{Nutrients in lake water}

Nitrogenous salts are; ammonia, nitrite, nitrate and total nitrogen. Bacteria produce ammonia as a result of oxidation of organic matter for energy, hydrolyzed protein and biological processes for some organisms that reduce the nitrogen and transform into ammonia; a toxic gas for the aquatic environment (Faragallah, 2009).

Nitrites are formed by the oxidation of bacteria to the inorganic materials for energy. This compound is unstable; it is oxidized by certain bacteria and 
converted into nitrate or reduced by other bacteria, the opposite of the first converts to ammonia. Nitrite is one of toxic compounds which combine with hemoglobin in the blood and prevents it from carrying oxygen to the body, especially in children and cause serious diseases in the blood. Nitrates are result in oxidation nitrites and urea by oxidizing bacterial species. Also it is produced from the nitrogen gas in the air and coming off in the rain water in the form of nitrate. Ammonia is the major nitrogenous product of the bacterial decomposition of organic matter containing nitrogen, and is an important excretory product of invertebrates and vertebrates. As for the utilization of nitrogenous materials, ammonia is the preferred inorganic source because of its ease uptake and incorporation into amino acids ( $\mathrm{N}$-assimilation) (Faragallah, 2009).

In present study, concentration of ammonia ranged between 14.73 and $1485 \mu \mathrm{g} / \mathrm{l}$. Ammonia contents in Lake Qarun showed high fluctuations, the values showing an increase at the stations facing the outlet of the two drains (Station 1 and 7), and it varied between a minimum value of $14.73 \mu \mathrm{g} / \mathrm{l}$ recorded at station II in summer and maximum one of $1485 \mu \mathrm{g} / \mathrm{l}$ recorded at station 1 in summer also. On the other hand, the concentration of ammonia in the drains fluctuated between $42.42-1485 \mu \mathrm{g} / \mathrm{l}$. The $\mathrm{PO}_{4}-\mathrm{P}$ in Lake Qarun water varied between $1.453 .4 \mu \mathrm{g} / \mathrm{l}$ at sit VIII and $498.4 \mu \mathrm{g} / \mathrm{l}$ at sit I. The relative high values of PO4-P $(498.4 \mu \mathrm{g} / \mathrm{l})$ were observed in (summer season) in the station VIII. The $\mathrm{PO}_{4}^{3-}$ and total phosphorus (TP) concentrations showed lower rates than that measured in the same lake by Abdel-Satar et al. (2010) and ranged between (0.235-1.074 mg/l). This reflects the indirect negative effect of algal blooming on the food web by decreasing the amount of edible phytoplankton that zooplankton and other primary consumer need to survive on (NOAA, 2009).

\section{References}

Abdel-Halim, A.M. and Khairy, H.M. (2007). Potential impact of some abiotic parameters on a phytoplankton community in a confined bay of the Eastern Mediterranean Sea: Eastern Harbour of Alexandria, Egypt. Mediterranean Marine Science, 8(2): 49-64.

Abou El-Gheit, EN Abdo MH, Mahmoud SA (2012). Impacts of Blooming Phenomenon on Water Quality and Fishes in Quarun Lake, Egypt. International Journal of Environmental Science and Engineering. 3:11-23.
Ali, F.K.; El-Shafai, S.A.; Samhan, F.A. and Khalil, W.K.B. (2008). Effect of water pollution on expression of immune response genes of Solea aegyptiaca in Lake Qarun. African Journal of Biotechnology, 7(10):1418-1425.

APHA (1995). Standard methods of the examination of water and waste water. New York 1193.

Arahal, D.R. and Ventosa, A. (2006). The family Halomonadaceae. In The Prokaryotes: a Handbook on the Biology of Bacteria, 3rd edn, vol. 6, pp. 811-835.

Beger, H. (1942). The values and importance of limiting concentrations in determining the hygientic quality of water. Part I, KI. Mtt. Ver. Wasser, Buden, and Lufthyg. 18, 15.

Ben Ali Gam, Z.; Abdelkafi, S.; Casalot, L.; Tholozan, J. L.; Oueslati, R. and Labat, M. (2007). Modicisalibacter tunisiensis gen. nov., sp. nov., an aerobic, moderately halophilic bacterium isolated from an oil field water injection sample, and emended description of the family Halomonadaceae Franzmann. Int J Syst Evol Microbiol 57, 2307-2313. Chaturvedi AK, Myers L, Hammons AF, Clark RA, Dunlap K, Kissinger PJ, Hagensee ME.(2005). Prevalence and clustering patterns of human papillomavirus genotypes in multiple infections. Cancer Epidemiol Biomarkers Prev. 14(10):2439-45.

Delince, G. (1992). The ecology of the fish pond ecosystem with special reference to Africa. Text book, kluwer Academic Publishers 230pp.

Dyrssen, D. and Wedborg, M. (1980). Major and minor elements, chemical speciation in estuarine waters. In: E. Olausson and I. Cato. Chemistry and biogeochemistry of estuaries, John Wiley and Sons. Chichester, pp. 71-119.

El-Shabrawy, G. M. \& O. E. Taha, (1999). Effect of grazing pressure on phytoplankton assemblage in Lake Qarun, El Fayum, Egypt. Egyptian Journal of Aquatic research, 3: 81-90.

Erez, J.; Krom, M.D. and Neuwirth, T. (1990). Daily oxygen variation in marine fishponds. Elat. Israel. Aquacul., 84: 289 - 305.

Faragallah, H. M.; Tadros, H. R. Z. and Okbah, M.A. (2009). Nutrient salts and chlorophyll-a during short term scale in the Eastern Harbour, Alexandria (Egypt). Egyptian Journal Aquatic Research, 35(3): 243-250.

Franzmann, P.D., Wehmeyer, U. and Stackebrandt, E. (1988). Halomonadaceae fam. nov., a new family of the class Proteobacteria to accommodate the genera Halomonas and Deleya. Syst Appl Microbiol 11, 16-19. 
George Garrity, Don J. Brenner, Noel R. Krieg, James R. Staley (2005). Bergey's Manual ${ }^{\circledR}$ of Systematic Bacteriology: Volume 2: The Proteobacteria, Part B: The Gammaproteobacteria $\left(2^{\text {nd }}\right.$ Ed.). Springer. ISBN 0387241442.

Goher, M.E., (2002). Chemical studies on the precipitation and dissolution of some chemical elements in Qarun Lake (p. 359). Ph.D. thesis, Faculty of Science, Al-Azhar University.

Grasshoff K. (1976). Methods of seawater analysis. Verlag Chemie, GmbH, D-6940 Weinheim, West Germany, 150 p.

Grasshoff, G. (1975). The hydrochemistry of land locked basins. Fjords Chemical Oceanography, 2: 568-574.

Grasshoff, K.; Kremling. K. and Ehrhardt, M. (1999). Methods of seawater Analysis, 3 rd edition, Weinheim; New York, Wiley-VCH, P. 600.

Guffanti, A. A.; Blanco, R.; Benenson, R.A. and Krulwich, T.A. (1980). Bioenergetic Properties of Alkaline-tolerant and Alkalophilic Strains of Bacillus firmus. Microbiology 119 (1):79-86.

Hamza, W.R. (1985). Phytoplankton production in lake Manzalah, Egypt. M.Sc. Thesis Faculty of Science, Alexandria University Egypt.

Hentschel, U.; Schmid, M.; Wagner, M.; Fieseler, L.; Ger-nert, C. and Hacker, J. (2001).Isolation and phylogenetic analysis of bacteria with antimicrobial activates from the Mediterranean sponges Aplysina aerophoba and Aplysina cavernicola. FEMS J. Micro. Eco., 35: 305-312.

International Organization for Standardization (ISO). Water quality - Detection and enumeration of coliform organisms, thermotolerant coliform organisms and presumptive Escherichia coli - part 2: multiple tube (most probable number) method Rep No 9308-2. Geneva, Switzerland: International Organization for Standardization (ISO); 1990.

International Organization for Standardization (ISO). Water quality detection and enumeration of streptococci - part 2: methods by membrane filtration Rep No 7899/2. Geneva, Switzerland: International Organization for Standardization (ISO); 1984.

Kim, K.K.; Lee J. S.; and Stevens D. A. (2013).Microbiology and epidemiology of Halomonas species. Future Microbiol. 8(12):1559-73.

Koroleff, F. (1969). Determination of ammonia as indophenol blue. International Council for the Exploration of the sea (ICES), p8.

Krom, M.D.; Neori, A. and Van Rijn, J. (1989).Importance of water flow rate in controlling water quality processes in marine and freshwater fishponds. Israel. J. Aquacul. 41; 23- 33.
Leiser W.L., H. Frederick W. Rattunde, HansPeter Piepho, Eva Weltzien, Abdoulaye Diallo, Abocar Toure, and Bettina I.G.(2015). Haussmann Phosphorous Efficiency and Tolerance Traits for Selection of Sorghum for Performance in Phosphorous-Limited Environments. Crop Sci. 55:111 .

Lim, J. M.; Yoon J. H.; Lee J. C.; Jeon, C.O.; Park, D.J.; Sung C. and Kim C. J. (2004). Halomonas koreensis sp. nov., a novel moderately halophilic bacterium isolated from a solar saltern in Korea. Int. J Syst Evol Microbiol. 54(Pt 6):2037-42.

López-Cortés, A.; Schumann, P.; Pukall, R. and Stackebrandt E. (2006). Exiguobacterium mexicanum sp. nov. and Exiguobacterium artemiae sp. nov., isolated from the brine shrimp Artemia franciscana. Syst Appl Microbiol. 29(3):183-90.

Luettich, R. A., D.R.F. Harleman, and L. Somlyo'DY. (1990). Dynamic behaviour of suspended sediment concentrations in a shallow lake perturbed by episodic wind events. Limnol. Oceanogr. 35: 1050-1067.

Madkour, F.; Dorgham, M. and Fahmy, M. (2007). Short term scale observations on phytoplankton in the Eastern Harbour of Alexandria, Egypt. Egyptian Journal of Aquatic Research, 33(1): 193-209.

Mansour, S.A.; Sidky, M.M. (2003). Ecotoxicological studies, The first comparative study between Lake Garun and Wadi El-Rayan ... 2003, 82, 181-189.

Medulla, A.I. (1951). Test for Traces of organic matter in water. Anal.Chem. 23, 1318.

$$
\text { Ministry of Health, Egypt. }
$$

Microbiological standards of the Egyptian.

Moor, J.W. and S. Ramamoorthy (1984). Heavy metals in natural waters, Springer Verlag, New Yourk, USA, 268p.

NOAA,(2009). National Oceanographic and Atmospheric Administration, Announces an Experimental Harmful Algal Blooms, Forecast Bulletin for Lake Erie.

Ntougias, S.; Zervakis, G. I. and Fasseas, C. (2007). Halotalea alkalilenta gen. nov., sp. nov., a novel osmotolerant and alkalitolerant bacterium from alkaline olive mill wastes, and emended description of the family Halomonadaceae Franzmann et al. 1989, emend. Dobson and Franzmann 1996. Int J Syst Evol Microbiol 57, 1975-1983.

Peconek, J.; Gruber, C.; Gallego, V.; Ventosa, A.; Busse, H.-J.; Kampfer, P.; Radax, C. and StanLotter, H. (2006). Reclassification of Pseudomonas beijerinckii Hof 1935 as Chromohalobacter 
beijerinckii comb. nov., and emended description of the species. Int J Syst Evol Microbiol 56, 1953-1957.

Rabeh, S.A. (2012). Monitoring of Microbial Pollution in Lake Qarun, A Closed Saline Lake in ElFayoum Governorate, Egypt.

Romano, I.; Giordano, A.; Lama, L.; Nicolaus, B. and Gambacorta, A. (2005). Halomonas campaniensis sp. nov., a haloalkaliphilic bacterium isolated from a mineral pool of Campania Region, Italy. Syst Appl Microbiol 28, 610-618.

Sabae, S.Z. (1993). Studies on Aquatic Bacteria in Lake Qarun, Fayoum, Egypt. M.sc. Thesis, Faculty of Science, Tanta University, 168pp.

Sabae, S.Z. (1996). Bacteriological and Chemical Studies on Benthic Layers of Lake Qarun, Faiyum, Egypt. Ph. D. Thesis, Faculty of Science, Tanta University, 192pp.

Sabae, S.Z. and Ali, M.H. (2004). Distribution of nitrogen cycle bacteria in relation to physicochemical conditions of a closed saline lake (Lake Qarun, Egypt). Journal of the Egyptian 44. Academic Society of Environmental Development, 5:145-167.

Sabae, S.Z. and Mohamed, F.A.S. (2015). Effect of Environmental Pollution on the Health of Tilapia spp. from Lake Qarun. Global Veterinaria 14(3): 304-328.

Sabae, S.Z. and Rabeh, S.A. (2000). Bacterial indices of sewage pollution in Lake Qarun, Fayoum, Egypt. Egyptian Journal of Aquatic Biology and Fisheries, 4:103-116.

Sanchez-Porro, C.; de la Haba, R.R.; SotoRamirez, N.; Marquez,M. C.; Montalvo-Rodri Guez, R. and Ventosa, A. (2009). Description of Kushneria aurantia gen. nov., sp. nov., a novel member of the family Halomonadaceae, and a proposal for reclassification of Halomonas marisflavi as Kushneria marisflavi comb. nov., of Halomonas indalinina as Kushneria indalinina comb. nov. and of Halomonas avicenniae as Kushneria avicenniae comb. nov. Int J Syst Evol Microbiol 59, 397-405.
Sieburth, J.M.C.N. (1968). Observations on Bacteria planktonic in Narragansett Bay, Rhode Island. A resume proceeding of the U.S. Japan Seminar on Marine microbiology. Bullten of Misaki, Marine Biology Institute, Kyoto University, 12: 49-64.

Strickland, J.D. and Parsons, T.R. (1972). A Practical handbook of sea water analysis, Canada Ottawa: 311 p.

Tayel, F.T.R.; Fahmy, M.A. and Shriadah, M.M.A. (1996). Studies on the physico-chemical characteristics of Mex Bay and New Dekhalia Harbour waters of Alexandria, Egypt. Bull. Nat. Inst. Of Oceanogr. and Fish., A.R.E., 22: 1-18.

Verduin, J. (1964). Changes in Western Lake Erle during the period 1948-1962. Verh. internat. Verein. Limnol., vol., 15: 639-644p.

Wolf, A.; Fritze, A.; Hagemann, M. and Berg, G. (2002): Stenotrophomonas rhizophila sp. nov., a novel plant-associated bacterium with antifungal properties. Int J Syst Evol Microbiol. 52(Pt 6):193744.

Wooster, w. s., A. J. LEE, AND G. DIETFWH. (1969). Redefinition of salinity. Int. Mar. Sci.,7( 1) : 4-5. A\&o in Limnol. Oceanog., 14: 437-438.

Wu, G.; Wu, X. Q., Wang, Y. N.; Chi, C.Q.; Tang, Y. Q.; Kida, K.; Wu, X. L. and Luan, Z.K. (2008). Halomonas daqingensis sp. nov., a moderately halophilic bacterium isolated from an oilfield soil. Int J Syst Evol Microbiol 58, 2859-2865.

Zaghloul, F.A. (1976). Plankton production and composition in the Nile water between Edfina and Rashid in relation to environmental conditions. M.Sc. Thesis. Faculty of Science, Alexandria University, pp. 273. 